\title{
Contribution of nitrogen derived from mineral supplementation for soybean seedlings
}

\author{
Contribuição do nitrogênio derivado da suplementação mineral \\ em sementes para plântulas de soja
}

\author{
Gerusa Massuquini Conceição', Thomas Newton Martin² , Gustavo Brunetto ${ }^{3}$, \\ Rogério Luiz Backes ${ }^{2}$, Fabrício Fuzzer de Andrade ${ }^{2}$, Manoela Beche ${ }^{2}$
}

\author{
${ }^{1}$ Universidade Regional do Noroeste do Estado do Rio Grande do Sul/UNIJUÍ, Departamento de Agronomia, Ijuí, RS, Brasil \\ 2Universidade Federal de Santa Maria/UFSM, Departamento de Fitotecnia, Santa Maria, RS, Brasil \\ ${ }^{3}$ Universidade Federal de Santa Maria/UFSM, Departamento de Solos, Santa Maria, RS, Brasil \\ ${ }^{*}$ Corresponding author: martin.ufsm@gmail.com \\ Received in June 28, 2017 and approved in December 6, 2017
}

\begin{abstract}
Seeds can absorb N from mineral supplementation, thus stimulating seedling development in soybeans (Glycine max (L.) Merrill). This study aimed to evaluate the contribution to soybean seedlings of $\mathrm{N}$ derived from mineral supplementation in seeds with different nutritional contents. Seeds of the cultivar BMX Potência RR received mineral supplementation enriched with $2.5 \%$ excess ${ }^{15} \mathrm{~N}$. The treatments were performed in seeds in two lots, one with high and one with low nutritional content. At 2, 6 and 10 days after sowing on paper towels, the seedlings were collected and separated into cotyledons, roots and shoots. Dry matter production, root length and root volume were assessed. Total $\mathrm{N}$ and ${ }^{15} \mathrm{~N}$ values were analyzed in the seedling organ tissues. The seeds from the lot with lower nutritional content absorbed more $\mathrm{N}$ from the mineral supplement, which was accumulated in the cotyledons and redistributed to the root systems and cotyledons. At 10 days after sowing, most of the $\mathrm{N}$ in the organs of soybean seedlings was derived from the seed reserves, regardless of nutritional content. Thus, application of $\mathrm{N}$ through mineral supplementation is of low importance for the development and nutrition of seedlings.
\end{abstract}

Index terms: Glycine max (L.) Merrill; absorption; distribution; ${ }^{15} \mathrm{~N}$.

\begin{abstract}
RESUMO
Sementes podem absorver $\mathrm{N}$ de suplementos minerais, estimulando o desenvolvimento de plântulas. O estudo objetivou avaliar a contribuição de $\mathrm{N}$ derivado da suplementação mineral em sementes com diferentes teores nutricionais, para plântulas de soja. Sementes de dois lotes da cultivar BMX Potência RR, contrastantes quanto ao teor nutricional, foram submetidas a aplicação de suplemento mineral enriquecido com 2,5\% átomos de ${ }^{15} \mathrm{~N}$ em excesso. Aos 2, 6 e 10 dias após a semeadura em papel toalha, plântulas foram coletadas, separadas em cotilédones, sistema radicular e parte aérea. A produção de matéria seca, o comprimento e volume do sistema radicular foram avaliados. No tecido dos órgãos das plântulas foram analisados os totais de $\mathrm{N}$ e ${ }^{15} \mathrm{~N}$. As sementes derivadas do lote com menor teor nutricional absorveram mais $\mathrm{N}$ do suplemento mineral, que foi acumulado nos cotilédones e redistribuído para o sistema radicular e parte aérea. A maior parte do N na soja ao longo de 10 dias após a semeadura é derivada das reservas da semente independentemente do teor nutricional inicial. A aplicação de $\mathrm{N}$ via suplementação mineral é de pouca importância para o crescimento e desenvolvimento de plântulas.
\end{abstract}

Termos para indexação: Glycine max (L.) Merrill; absorção; distribuição; ${ }^{15} \mathrm{~N}$.

\section{INTRODUCTION}

Soybean seeds (Glycine max (L.) Merrill) with a greater amount of internal reserves produce seedlings with better initial development, which contributes to better establishment in the field and, consequently, better yields (Seyyedi et al., 2015). In soybeans, approximately $40 \%$ of the reserves contain $\mathrm{N}$, primarily proteins and amino acids (Wang et al., 2016). The rest of the reserves are composed of carbohydrates, lipids and other mineral nutrients (Sawan et al., 2011; Seyyedi et al., 2015).
The application of mineral supplements containing $\mathrm{N}$ at the time of seed treatment, before sowing, can be a strategy to increase the internal concentration of $\mathrm{N}$ in seeds and possibly in seedlings (Shah et al., 2011, 2012; Islam et al., 2016). The applied $\mathrm{N}$ may be passively transported to the apoplast of seeds, along with water during the process of soaking. Then, the applied $\mathrm{N}$ may be moved to the cytoplasm of cells through protein transporters that facilitate the transport of selective solutes whose movement depends on the electrochemical gradient of $\mathrm{H}^{+}$(Miller et al., 2009; Shinmach et al., 2010), the concentration of solutes 
from the environment and the demand of the plant (Yin et al., 2014). These proteins belong to three groups: ATPbinding cassette, OPTs and PTR/NTR1, which transport peptides that range from 6 to 59 amino acids (Ramos et al., 2011). Subsequently, $\mathrm{N}$ can be transported to areas of intense development and growth in the embryonic axis and then to the root. In seeds, transporters in the PTR family are associated with $\mathrm{N}$ mobilization during germination; they act in the transport of nutrients over long distances to growth tissues (Tnani et al., 2013).

$\mathrm{N}$ derived from the mineral supplement, if absorbed by the seeds, can accelerate radicle emission and optimize the speed of growth of seedling roots and shoots during emergence (Kim et al., 2011; Narasimhan et al., 2013). This growth is desirable in adverse conditions, for example, when seeds are sown at greater depths or in soils with higher rates of compression (Pereira et al., 2015). However, there is little information in the literature about the real contribution of $\mathrm{N}$ derived from mineral supplementation on germination and seedling development in soybeans. This information can be determined by using ${ }^{15} \mathrm{~N}$ stable isotopes, which allow researchers to track precisely the quantity of fertilizerderived $\mathrm{N}$ that is absorbed and distributed to seedlings (Brunetto et al., 2014; Chalk et al., 2014). Thus, the present study aims to evaluate the contribution to soybean seedlings of $\mathrm{N}$ derived from mineral supplementation in seeds with different nutritional contents.

\section{MATERIAL AND METHODS}

\section{Location of experiment and plant material}

The study was carried out in the Seed Research Laboratory, Department of Plant Science, Federal University of Santa Maria (UFSM), in Santa Maria, Rio Grande do Sul (RS), Brazil, in the month of October 2014.

Soybean seeds of cultivar BMX Potência RR, from lots with different nutritional contents, were classified as having high or low nutritional content. The lots were produced in 2013/14. The water content of the seeds was almost $12 \%$, and the thousand-seed weight showed average values of 148 and 153 grams. Table 1 shows the characterization of seed lots.

\section{Treatments and mineral supplementation of seeds}

The treatments were arranged in a $2 \times 3 \times 3$ factorial design (lots with mineral supplementation vs. seedling components vs. time) for different seedlings components and in a $2 \times 3$ factorial design (lots with mineral supplementation vs. time) for the variables obtained from the entire seedling. The experimental design was completely randomized with four replicates.

The seeds in lots of low and high nutritional content received mineral supplementation, which consisted of $48 \mathrm{~g}$ $\mathrm{L}^{-1} \mathrm{~N}, 80 \mathrm{~g} \mathrm{~L}^{-1} \mathrm{P}_{2} \mathrm{O}_{5}, 16 \mathrm{~g} \mathrm{~L}^{-1} \mathrm{~K}_{2} \mathrm{O}, 16 \mathrm{~g} \mathrm{~L}^{-1} \mathrm{Ca}, 8 \mathrm{~g} \mathrm{~L}^{-1} \mathrm{Mg}, 3.2$ $\mathrm{g} \mathrm{L}^{-1} \mathrm{Co}, 8 \mathrm{~g} \mathrm{~L}^{-1} \mathrm{Cu}, 32 \mathrm{~g} \mathrm{~L}^{-1} \mathrm{Mn}, 160 \mathrm{~g} \mathrm{~L}^{-1} \mathrm{Mo}, 1.6 \mathrm{~g} \mathrm{~L}^{-1} \mathrm{Ni}$ and $16 \mathrm{~g} \mathrm{~L}^{-1} \mathrm{Zn}$. For ${ }^{15} \mathrm{~N}$ enrichment, the mineral supplement was manufactured without $\mathrm{N}$; subsequently, $48 \mathrm{~g} \mathrm{~L}^{-1} \mathrm{~N}$ was added to the supplement in the form of urea $(44 \% \mathrm{~N})$, enriched with $2.5 \%$ excess ${ }^{15} \mathrm{~N}$ atoms. One $\mathrm{mL}$ of mineral supplement containing ${ }^{15} \mathrm{~N}$ plus $2 \mathrm{~mL}$ of distilled water was added to 500 grams of soybean seeds in each batch and packed in 3 L plastic bags for better distribution of the product on the seeds. The application was performed with a $3 \mathrm{~mL}$ syringe. During the implementation of the supplement, the seeds were homogenized by manual agitation of the plastic bags.

\section{Assessments}

Assessments of water content, thousand-seed weight, first count of germination test, and germination were performed according to the Rules for Seed TestingRAS (Brasil, 2009). For the evaluation of seedling length and root volume, the seeds were germinated in a B.O.D. (Bio-Oxygen Demand) chamber at a temperature of $25{ }^{\circ} \mathrm{C}$, using paper rolls moistened with distilled water as a substrate. Five normal seedlings per replicate were randomly collected at 2, 6 and 10 days after sowing. Soon after that, the seedlings were separated into roots, shoots and cotyledons. The roots and shoots were placed on acrylic slides and then placed on an EPSON Expression 1831 scanner, fitted with additional light (TPU) and with a resolution of 600dpi. The software WinRhizo Pro 2013 was used for measuring root length, root volume and shoot length. Subsequently, the three parts of the plants were dried in a forced-air circulation oven at $65^{\circ} \mathrm{C}$ until

Table 1: Characterization of lots of soybean seeds with high and low nutritional contents.

\begin{tabular}{|c|c|c|c|c|c|c|}
\hline Lot & First Count & Germination & $\mathrm{N}$ & $\mathrm{P}$ & $\mathrm{K}$ & $\mathrm{Ca}$ \\
\hline & \multicolumn{2}{|c|}{ (\%) } & \multicolumn{3}{|c|}{$\left(\mathrm{g} \mathrm{kg}^{-1}\right)$} & $\left(g^{m g} g^{-1}\right)$ \\
\hline Low & 80 & 89 & 70.30 & 3.87 & 11.75 & 2.00 \\
\hline High & 86 & 92 & 81.70 & 4.07 & 17.25 & 2.25 \\
\hline
\end{tabular}


dry (72 h). After that, the samples were removed from the oven, placed in a desiccator for 15 minutes and weighed on a $0.001 \mathrm{~g}$ precision scale to determine dry mass of the roots, shoots and cotyledons. The results were expressed in $\mathrm{mg}$ seedling ${ }^{-1}$. Subsequently, tissue samples were prepared according to the procedure described by Trivelin (2001). The analyses of ${ }^{15} \mathrm{~N}$ and total $\mathrm{N}$ in the tissues were performed with a mass spectrometer.

\section{Calculations and statistical analysis}

Based on the results of the analyses of tissue samples, calculations were made of atom $\%{ }^{15} \mathrm{~N}$ excess (Equation 1 ), $\mathrm{N}$ derived from fertilizer (Ndff) (Equation 2 and 3) and $\mathrm{N}$ derived from seed reserves (Ndsr) (Equation 4 and 5) for the different seedling components.

${ }^{15} \mathrm{~N}$ excess atoms $(\%)=\%{ }^{15} \mathrm{~N}$ atoms in the sample $-0,3663 \%$

$\operatorname{Ndff}(\%)=\frac{\%{ }^{15} \mathrm{~N} \text { atoms excess in the sample }}{\% \text { atom }{ }^{15} \mathrm{~N} \text { in fertilizer }} \times 100$

$N d f f(m g)=$ total $N$ in the sample $(m g) \times \frac{\%{ }^{15} N \text { atoms excess in the sample }}{\% \text { átom }{ }^{15} N \text { in fertilizer }}$

$N d r s(\%)=100-\% N d f f$

$N d r s(m g)=$ total $N$ in the sample $(m g)-N d f f(m g)$

The results were submitted to analysis of variance (ANOVA); when significant by the F-test, the means were compared by the Scott-Knott test at $5 \%$ probability of error. The software programs used for the analyses were SOC (Embrapa, 1997) and Genes (Cruz, 2006).

\section{RESULTS AND DISCUSSION}

The interaction between seedling component and assessment time was significant for the variables dry matter, atom $\%{ }^{15} \mathrm{~N}$ excess, total $\mathrm{N}(\mathrm{mg}), \% \mathrm{Ndff}$ and $\% \mathrm{Ndsr}$. The interaction between lot and evaluation time was significant for Ndsr (mg). The interaction between lot and seedling organ was significant for total $\mathrm{N}(\%, \mathrm{mg})$ and $\mathrm{Ndsr}(\mathrm{mg})$. There was a significant effect of lot, seedling organ and assessment time for all analyzed variables. For the entire seedling, the interaction between lot and assessment time was significant only for Ndff. There was a significant effect of assessment time for total dry matter (DM) and Ndff and a significant effect of lot for all analyzed variables (Table 2).
Total dry matter of seedlings decreased throughout the assessment period (Table 3). This may have occurred because there is a high demand for metabolic energy during germination and development, as a result of intense respiratory activity that involves not only gas exchanges but also dry matter loss (Oliveira et al., 2015). The highest dry matter production in all assessments periods $(2,6$, and 10 days after sowing) occurred in the cotyledons, followed by the shoots and roots. With the decrease in dry matter and in the values of total $\mathrm{N}$ (mg) of the cotyledons throughout the assessment period, there was an increase in dry matter and total $\mathrm{N}$ in roots and shoots. This increase occurred because the normal growth of seedlings depends on the fraction of mobilized reserves as well as on conversion efficiency (Seyyedi et al., 2015). Thus, the synthesis of proteins in the cotyledons is essential for two reasons: it is a source of metabolic energy, and it helps construct plant tissues. The reason lies in the fact that imbibition is followed by digestion, mobilization and transport of these cotyledonary reserves, which will sustain growth (Goyaga et al., 2011).

The highest atom $\%{ }^{15} \mathrm{~N}$ excess and $\% \mathrm{Ndff}$ in the first assessment period, at 2 days after sowing, were found in the roots, followed by the cotyledons (Table 3 ). At the second and third assessment times, at 6 and 10 days after sowing, respectively, the lowest atom $\%{ }^{15} \mathrm{~N}$ excess was found in the cotyledons. This low excess occurred because the $\mathrm{N}$ applied via mineral supplementation was absorbed (as well as sucrose, phosphorous compounds and, mainly, amino acids, as early as in Phase II of the germination process) and rapidly translocated to the embryonic axis and, subsequently, redistributed for growth of the root, where it is actually needed for enzymatic reactions (Henning et al., 2010; Tairo; Ndakidemi, 2013). However, the higher atom $\%{ }^{15} \mathrm{~N}$ excess in the root at 2, 6 and 10 days after sowing did not result in a greater quantity of Ndff (mg). This may be because of lower dry matter production.

The highest values of $\mathrm{Ndsr}(\%, \mathrm{mg})$ were found in the cotyledons (Table 3 ). In the course of the assessment at 2, 6 and 10 days after sowing, in addition to a reduction in $\mathrm{Ndsr}$ (mg) in this component, there was an increase in Ndsr in the roots and shoots. The percentage of Ndff in organs of the seedlings from seeds of high and low nutritional content evaluated at 2, 6 and 10 days after sowing were $0.12 \%$ on average. This value indicates that approximately $99.87 \%$ of $\mathrm{N}$ present in the tissues of the organs of seedlings was derived from seed reserves rather than from the mineral supplement added via seed treatment. This probably occurred because the proteins stored in the cotyledons of legumes, which derive mainly from $\mathrm{N}_{2}$ from the biological nitrogen fixation process (Pauferro et al., 2010), are the 
major source of nutrients for the growth of the embryo and, subsequently, the roots and shoots (Schlereth et al., 2000; Goyoaga et al., 2011; Liu et al., 2015). Hence, the proteins stored in cotyledons suffer the action of enzymes (proteases and peptidases) and are degraded to amino acids, which will later be redistributed to the points of growth, sustaining the heterotrophic period of the life of the seedling and directly influencing its vigor (Sawan et al., 2011; Krueger et al., 2013). Studies on the content and distribution of proteins during germination and seedling development have shown a reduction in protein content in the cotyledons from 0.18 to 0.10 grams between 0 and 9 days (Goyoaga et al., 2011).

Table 2: Summary of analysis of variance ( $\mathrm{Pr}>\mathrm{Fc}$ ), mean square and level of significance for dry matter (DM), atom\% ${ }^{15} \mathrm{~N}$ excess, total nitrogen $(\mathrm{N} \%, \mathrm{mg}$ ), $\mathrm{N}$ derived from fertilizer ( $\mathrm{Ndff}, \%, \mathrm{mg}$ ) and $\mathrm{N}$ derived from seed reserves (Ndsr, \%, mg), in the organs of the seedlings (cotyledon, root and shoot) and entire seedling (total) of soybean from seeds with low and high nutritional content, assessed at 2, 6 and 10 days after sowing.

\begin{tabular}{|c|c|c|c|c|c|c|c|c|c|}
\hline \multirow[t]{2}{*}{ SV } & \multirow[t]{2}{*}{ DF } & \multicolumn{2}{|c|}{$\mathrm{DM}(\mathrm{mg})$} & \multicolumn{2}{|c|}{ atom $\%{ }^{15} \mathrm{~N}$ excess } & \multicolumn{2}{|c|}{ Total N (\%) } & \multicolumn{2}{|c|}{ Total N (mg) } \\
\hline & & QM & $\mathrm{Pr}>\mathrm{Fc}$ & QM & $\mathrm{Pr}>\mathrm{Fc}$ & $\mathrm{QM}$ & $\mathrm{Pr}>\mathrm{Fc}$ & QM & $\mathrm{Pr}>\mathrm{Fc}$ \\
\hline Lot $(A)$ & 1 & 1091.14 & 0.003 & 0.000 & 0.016 & 29.05 & 0.000 & 212.43 & 0.000 \\
\hline Component (D) & 2 & 1220074.41 & 0.000 & 0.000 & 0.000 & 5.19 & 0.000 & 5141.07 & 0.000 \\
\hline Assessment (C) & 2 & 50800.32 & 0.000 & 0.000 & 0.000 & 3.61 & 0.000 & 88.88 & 0.000 \\
\hline$A \times D$ & 2 & 207.16 & 0.162 & 0.000 & 0.080 & 0.68 & 0.028 & 46.29 & 0.000 \\
\hline$A \times C$ & 2 & 88.55 & 0.451 & 0.000 & 0.088 & 0.26 & 0.037 & 0.121 & 0.930 \\
\hline $\mathrm{D} \times \mathrm{C}$ & 3 & 75651.43 & 0.000 & 0.000 & 0.000 & 0.29 & 0.183 & 241.03 & 0.000 \\
\hline$A \times D \times C$ & 3 & 58.13 & 0.663 & 0.000 & 0.402 & 0.07 & 0.741 & 1.988 & 0.324 \\
\hline CV(\%) & & \multicolumn{2}{|c|}{4.73} & \multicolumn{2}{|c|}{17.68} & \multicolumn{2}{|c|}{6.32} & \multicolumn{2}{|c|}{8.83} \\
\hline \multirow[t]{3}{*}{ Mean } & & \multicolumn{2}{|c|}{220.68} & \multicolumn{2}{|c|}{0.0049} & \multicolumn{2}{|c|}{6.64} & \multicolumn{2}{|c|}{14.64} \\
\hline & & \multicolumn{2}{|c|}{ Ndff (\%) } & \multicolumn{2}{|c|}{$\mathrm{Ndff}(\mathrm{mg})$} & \multicolumn{2}{|c|}{ Ndrs (\%) } & \multicolumn{2}{|c|}{ Ndrs (mg) } \\
\hline & & QM & $\mathrm{Pr}>\mathrm{Fc}$ & QM & $\mathrm{Pr}>\mathrm{Fc}$ & QM & $\mathrm{Pr}>\mathrm{Fc}$ & QM & $\mathrm{Pr}>\mathrm{Fc}$ \\
\hline Lot $(A)$ & 1 & 0.003 & 0.015 & 0.000 & 0.000 & 0.003 & 0.015 & 211.99 & 0.000 \\
\hline Component (D) & 2 & 0.126 & 0.000 & 0.001 & 0.000 & 0.126 & 0.000 & 5135.83 & 0.000 \\
\hline Assessment (C) & 2 & 0.041 & 0.000 & 0.000 & 0.000 & 0.041 & 0.000 & 88.68 & 0.000 \\
\hline$A \times D$ & 2 & 0.001 & 0.057 & 0.000 & 0.081 & 0.001 & 0.057 & 46.30 & 0.000 \\
\hline$A \times C$ & 2 & 0.001 & 0.099 & 0.000 & 0.162 & 0.001 & 0.099 & 0.120 & 0.928 \\
\hline$D \times C$ & 3 & 0.014 & 0.000 & 0.000 & 0.000 & 0.014 & 0.000 & 240.61 & 0.000 \\
\hline$A \times D \times C$ & 3 & 0.000 & 0.419 & 0.000 & 0.707 & 0.000 & 0.419 & 1.98 & 0.325 \\
\hline $\mathrm{CV}(\%)$ & & \multicolumn{2}{|c|}{17.98} & \multicolumn{2}{|c|}{18.35} & \multicolumn{2}{|c|}{0.023} & \multicolumn{2}{|c|}{8.82} \\
\hline Mean & & \multicolumn{2}{|c|}{0.129} & \multicolumn{2}{|c|}{0.012} & \multicolumn{2}{|c|}{99.87} & \multicolumn{2}{|c|}{14.63} \\
\hline \multicolumn{10}{|c|}{ Entire seedling } \\
\hline $\mathrm{FV}$ & DF & \multicolumn{2}{|c|}{$\mathrm{DM}(\mathrm{mg})$} & Total & (mg) & $\mathrm{Nd}$ & ng) & Ndrs & $\mathrm{mg})$ \\
\hline & & QM & $\mathrm{Pr}>\mathrm{Fc}$ & QM & $\mathrm{Pr}>\mathrm{Fc}$ & QM & $\mathrm{Pr}>\mathrm{Fc}$ & QM & $\mathrm{Pr}>\mathrm{Fc}$ \\
\hline Lot $(A)$ & 1 & 2909.94 & 0.005 & 566.47 & 0.000 & 0.000 & 0.000 & 565.41 & 0.000 \\
\hline Assessment (D) & 2 & 24678.52 & 0.000 & 6.61 & 0.211 & 0.000 & 0.010 & 6.60 & 0.210 \\
\hline$A \times D$ & 2 & 362.54 & 0.302 & 2.62 & 0.522 & 0.000 & 0.034 & 2.61 & 0.522 \\
\hline CV(\%) & & & & & & & & 39 & \\
\hline Mean & & 588 & & & & & 32 & & \\
\hline
\end{tabular}

$\mathrm{CV}=$ Coefficient of variation; SV= Source of variation; $\mathrm{DF}=$ degrees of freedom. 
Table 3: Dry matter (DM), atom\% ${ }^{15} \mathrm{~N}$ excess, total $\mathrm{N}, \mathrm{N}$ derived from fertilizer ( $\mathrm{Ndff}$ ) and $\mathrm{N}$ derived from seed reserves (Ndsr) in the cotyledon (Cot), root (Rs), shoot (S) and entire seedling of soybeans derived from seeds with low and high nutritional content, assessed at 2, 6 and 10 days after sowing.

\begin{tabular}{|c|c|c|c|c|c|c|c|c|}
\hline \multirow{2}{*}{$\begin{array}{l}\text { Days after } \\
\text { sowing }\end{array}$} & \multirow{2}{*}{$\begin{array}{c}\text { Seedling } \\
\text { Component }\end{array}$} & \multirow{2}{*}{$\mathrm{DM}(\mathrm{mg})$} & \multirow{2}{*}{$\begin{array}{c}\text { atom\% } \%{ }^{15} \mathrm{~N} \\
\text { excess }\end{array}$} & \multirow{2}{*}{$\begin{array}{l}\text { Total N } \\
\text { (mg) }\end{array}$} & \multicolumn{2}{|c|}{ Ndff } & \multicolumn{2}{|c|}{$\mathrm{Ndsr}$} \\
\hline & & & & & (\%) & (mg) & (\%) & (mg) \\
\hline \multirow{4}{*}{2} & Cot & $616.87 a^{1} A^{2}$ & $0.0028 \mathrm{bA}$ & $37.49 a A$ & $0.07 \mathrm{bA}$ & $0.029 a A$ & $99.92 \mathrm{aA}$ & $37.46 a A$ \\
\hline & Rs & $30.21 b c$ & $0.0108 \mathrm{aA}$ & $1.77 \mathrm{bB}$ & $0.29 a A$ & $0.005 \mathrm{bA}$ & $99.71 b C$ & $1.77 \mathrm{bB}$ \\
\hline & S & $\#$ & \# & \# & \# & \# & \# & \# \\
\hline & Total & $647.09 \mathrm{~A}$ & - & $39.27 \mathrm{~A}$ & - & $0.035 a$ & - & $39.23 \mathrm{~A}$ \\
\hline \multirow{4}{*}{6} & Cot & $457.53 a B$ & $0.0022 c A$ & $31.46 \mathrm{aB}$ & $0.05 \mathrm{cA}$ & $0.018 a B$ & 99.94aA & $31.44 a B$ \\
\hline & Rs & $47.86 \mathrm{cB}$ & $0.0074 a B$ & $3.02 c B$ & $0.19 a B$ & $0.006 \mathrm{cA}$ & $99.80 \mathrm{cB}$ & $3.02 \mathrm{cB}$ \\
\hline & S & $76.37 \mathrm{bB}$ & $0.0059 \mathrm{bB}$ & $5.33 \mathrm{bB}$ & $0.15 \mathrm{bB}$ & $0.008 \mathrm{bA}$ & $99.84 \mathrm{bB}$ & $5.32 \mathrm{bB}$ \\
\hline & Total & 581.77B & - & $39.82 \mathrm{~A}$ & - & $0.034 a$ & - & $39.79 A$ \\
\hline \multirow{4}{*}{10} & Cot & $339.03 a C$ & $0.0020 c A$ & $23.55 \mathrm{aC}$ & $0.05 c \mathrm{~A}$ & $0.013 \mathrm{aC}$ & 99.94aA & $23.54 a C$ \\
\hline & Rs & $64.62 \mathrm{cA}$ & $0.0051 \mathrm{aC}$ & $4.36 \mathrm{cA}$ & $0.13 a C$ & $0.006 \mathrm{cA}$ & $99.86 \mathrm{cA}$ & $4.35 \mathrm{cA}$ \\
\hline & S & $132.96 \mathrm{bA}$ & $0.0030 \mathrm{bB}$ & $10.13 \mathrm{bA}$ & $0.07 \mathrm{bc}$ & $0.008 \mathrm{bA}$ & $99.92 \mathrm{bA}$ & $10.12 \mathrm{bA}$ \\
\hline & Total & $536.62 C$ & - & $38.04 \mathrm{~A}$ & - & $0.028 \mathrm{~B}$ & - & $38.01 \mathrm{~A}$ \\
\hline \multirow{3}{*}{ Lot } & \multirow{3}{*}{$\begin{array}{l}\text { Seedling } \\
\text { Component }\end{array}$} & \multirow{2}{*}{\multicolumn{2}{|c|}{ Total N }} & \multirow{3}{*}{$\begin{array}{l}\text { Ndrs (mg) } \\
\text { Days after } \\
\text { sowing }\end{array}$} & \multicolumn{4}{|c|}{ Entire seedling } \\
\hline & & & & & ot & Ndff & & \\
\hline & & $(\%)$ & (mg) & & LOT & (mg) & & - \\
\hline \multirow{5}{*}{ Low } & Cot & $5.91 \mathrm{bB}$ & $27.48 \mathrm{aB}$ & $27.46 a \mathrm{~B}$ & \multirow{3}{*}{2} & Low & $0.036 \mathrm{aA}$ & - \\
\hline & Rs & $5.73 \mathrm{bB}$ & $2.33 c B$ & $2.33 \mathrm{cB}$ & & high & $0.034 a A$ & - \\
\hline & S & $6.40 \mathrm{aB}$ & $6.55 \mathrm{bB}$ & $6.54 \mathrm{bB}$ & & & & - \\
\hline & \multirow[t]{2}{*}{ Total } & \multirow[t]{2}{*}{-} & \multirow[t]{2}{*}{$34.19 B$} & \multirow[t]{2}{*}{$34.16 \mathrm{~B}$} & \multirow{2}{*}{6} & Low & $0.037 a A$ & - \\
\hline & & & & & & high & $0.030 \mathrm{bA}$ & \\
\hline \multirow[t]{4}{*}{ High } & Cot & $7.34 \mathrm{bA}$ & 34.19aA & $34.17 a A$ & \multirow{4}{*}{10} & & & - \\
\hline & Rs & $6.73 \mathrm{cA}$ & $3.76 \mathrm{cA}$ & $3.76 \mathrm{cA}$ & & Low & $0.035 \mathrm{aA}$ & - \\
\hline & s & $8.14 \mathrm{aA}$ & $8.91 \mathrm{bA}$ & $8.90 \mathrm{bA}$ & & high & $0.022 \mathrm{bB}$ & - \\
\hline & Total & - & $43.90 \mathrm{~A}$ & $43.87 \mathrm{~A}$ & & & & - \\
\hline
\end{tabular}

$(1,2)$ Means followed by the same letter, lowercase letters in the column within the same period of collection and capital letters in the column between collection periods within the same lot, do not differ. \# Structure absent at the time of evaluation.

Values of total $\mathrm{N}(\%, \mathrm{mg})$ and $\mathrm{Ndsr}(\mathrm{mg})$ were higher in the organs and seedlings derived from the lot with high nutritional content (Table 3 and Table 4). The values for $\operatorname{Ndff}(\mathrm{mg})$ in seedlings from the lot with low nutritional content remained stable until 10 days after sowing. This did not occur in the lot with high nutritional content, probably because a lesser amount of $\mathrm{N}$ derived from the mineral supplement had been absorbed (Table 3), hence the values for Ndff decreased at the end of the assessment period.
The highest percentages of atom $\%{ }^{15} \mathrm{~N}$ excess and Ndff were found in seedlings from the lot with low nutritional content (Table 4). This occurred because of the lower concentration of $\mathrm{N}$ present in the seeds of this lot (Table 3). Responses of soybean to mineral supplementation depends on several factors, including the nutrient content of the seed (Campo et al., 2009). In the present study, the smaller amount of $\% \mathrm{Ndsr}$ in the seeds of the lot with low nutritional content may have induced the expression of high affinity transporter proteins (iHATS) 
when subjected to mineral supplementation, according to the results observed by Tnani et al. 2013. They studied the expression of genes of the family ZmPTR1 in corn seeds in the presence and absence of $\mathrm{N}$. This presence favored the absorption of $\mathrm{N}$ added via mineral supplementation, as the expression of genes that encode these carriers may not be regulated-up to that point-in the lot with high $\mathrm{N}$ content. This is possibly because seeds may have a sufficiently high $\mathrm{N}$ concentration for growth (White; Veneklaas, 2012; Yin et al., 2014). However, the greater absorption of fdN in this lot did not lead to greater growth of the roots and shoots of the seedlings. A probable reason is the low amount of $\mathrm{N}$ in the cell apoplast, where it can be made available for the construction of new tissues, growth and metabolism of seedlings (Liu et al., 2015).

The interaction between seed lot and assessment time was not significant for any of the morphological variables of seedlings (Table 5). There was a significant effect of seed lot on root length (RL), root volume (RV) and of assessment times for all analyzed variables. Seedling RL, RV and shoot length (SL) increased in the two lots at 2, 6 and 10 days after sowing, respectively

Table 4: Comparison of means of main effects $A, D$ and $C$ for dry matter (DM), atom $\% 15 \mathrm{~N}$ excess, $\mathrm{N}$ derived from fertilizer (Ndff) and N derived from seed reserves (Ndsr) in the cotyledon (TOC), root (Rs), shoot (S) and entire seedling of soybeans derived from seeds with low and high nutritional content, assessed at 2,6 and 10 days after sowing.

\begin{tabular}{|c|c|c|c|c|c|}
\hline \multirow[t]{2}{*}{ Lot } & \multirow[t]{2}{*}{$\mathrm{DM}$ (mg) } & \multirow[t]{2}{*}{ atom $\% 15 \mathrm{~N}$ excess } & \multicolumn{2}{|c|}{ Ndff } & \multirow[t]{2}{*}{$\% N d s r$} \\
\hline & & & $(\%)$ & (mg) & \\
\hline Low & $216.55 b 2$ & $0.0052 a$ & $0.14 a$ & $0.02 a$ & $99.87 a$ \\
\hline high & $224.81 a$ & $0.0043 b$ & $0.11 b$ & $0.01 b$ & $99.86 b$ \\
\hline Assessment & Total N (\%) & - & - & - & - \\
\hline 2 & $5.95 c 1$ & - & - & - & - \\
\hline 6 & $6.68 b$ & - & - & - & - \\
\hline 10 & $7.06 a$ & - & - & - & - \\
\hline \multicolumn{6}{|c|}{ Entire seedling } \\
\hline Lot & $\mathrm{DM}(\mathrm{mg})$ & Total N (mg) & Ndrs (mg) & - & - \\
\hline Low & $577.48 b$ & $34.19 b$ & $34.16 b$ & - & - \\
\hline \multirow[t]{2}{*}{ high } & $599.50 a$ & $43.90 \mathrm{a}$ & $43.87 a$ & - & - \\
\hline & $\mathrm{DM}(\mathrm{mg})$ & - & - & - & - \\
\hline 2 & $647.09 a$ & - & - & - & - \\
\hline 6 & $581.77 \mathrm{~b}$ & - & - & - & - \\
\hline 10 & $536.62 \mathrm{c}$ & - & - & - & - \\
\hline
\end{tabular}

$(1,2)$ Means followed by the same letter in the column within the same period of collection and lot, do not differ.

Table 5: Summary of analysis of variance ( $\mathrm{Pr}>\mathrm{Fc}$ ), mean square and level of significance for root length (RL), root volume (RV) and shoot length (SL) of soybean seedlings derived from seeds with low and high nutritional content, assessed at 2, 6 and 10 days after sowing.

\begin{tabular}{cccccccc}
\hline SV & DF & \multicolumn{2}{c}{$\mathrm{RL}(\mathrm{cm})$} & \multicolumn{2}{c}{$\mathrm{RV}\left(\mathrm{cm}^{3}\right)$} & \multicolumn{2}{c}{$\mathrm{SL}(\mathrm{cm})$} \\
\hline & \multicolumn{2}{c}{$\mathrm{QM}$} & $\mathrm{Pr}>\mathrm{Fc}$ & $\mathrm{QM}$ & $\mathrm{Pr}>\mathrm{Fc}$ & $\mathrm{QM}$ & $\mathrm{Pr}>\mathrm{Fc}$ \\
\hline Lot (A) & 1 & 49.50 & 0.012 & 0.001 & 0.016 & 0.238 & 0.289 \\
Assessment (B) & 2 & 11039.32 & 0.000 & 0.590 & 0.000 & 7779.00 & 0.000 \\
A × B & 2 & 12.27 & 0.545 & 0.000 & 0.55 & 0.401 & 0.16 \\
CV(\%) & \multicolumn{2}{c}{10.09} & \multicolumn{2}{c}{11.46} & \multicolumn{2}{c}{4.37} \\
Mean & \multicolumn{2}{c}{43.88} & 0.142 & \multicolumn{2}{c}{10.22} \\
\hline
\end{tabular}

$C V=$ Coefficient of variation; SV= Source of variation; $D F=$ degrees of freedom. 
(Table 6). The seedlings from seeds of the lot with high nutritional content showed better performance for RL and RV. This occurred because in seed lots with higher nutritional content, there is greater availability of $\mathrm{N}$ for the synthesis of nucleic acids, proteins and amino acids, causing changes in root architecture, especially at the beginning of development (White; Veneklaas, 2012; Narasimhan et al., 2013).

Table 6: Root length (RL), root volume (RV) and shoot length (SL) of soybean seedlings derived from seeds with low and high nutritional content, assessed at two, six and 10 days after sowing.

\begin{tabular}{|c|c|c|c|}
\hline \multirow{2}{*}{ Days after sowing } & \multicolumn{2}{|c|}{ Lot } & \multirow{2}{*}{ Mean } \\
\hline & Low & High & \\
\hline \multicolumn{4}{|c|}{--' } \\
\hline 2 & 2.31 & 2.33 & $2.33 c^{1}$ \\
\hline 6 & 53.44 & 57.55 & $55.50 \mathrm{~b}$ \\
\hline 10 & 71.59 & 76.08 & $73.84 a$ \\
\hline Mean & $42.45 b^{2}$ & $45.35 a$ & \\
\hline \multicolumn{4}{|c|}{$-\mathrm{RV}\left(\mathrm{cm}^{3}\right)$} \\
\hline 2 & 0.040 & 0.047 & $0.043 c$ \\
\hline 6 & 0.170 & 0.190 & $0.180 a$ \\
\hline 10 & 0.190 & 0.215 & $0.202 a$ \\
\hline Mean & $0.133 b$ & $0.151 a$ & \\
\hline 2 & \# & \# & \# \\
\hline 6 & 11.33 & 10.62 & $10.97 b$ \\
\hline 10 & 19.63 & 19.75 & $19.69 a$ \\
\hline Mean & 10.32 & 10.12 & \\
\hline
\end{tabular}

$(1,2)$ Means followed by the same letter, lowercase letters in the column within the same lot at different assessment times and on the line between the lots, do not differ from each other. \# Structure absent at the time of collection.

The biggest initial development of the root system, associated with dry matter accumulation of seedlings of the two lots (Table 4), reinforces the idea that the lot with lower nutritional content has the highest values of atom $\%{ }^{15} \mathrm{~N}$ excess, thus indicating greater absorption of Ndff (Table 3), which is not reflected in higher initial development, compared with the seedlings derived from the lot with high nutritional content. This partly explains why legume seeds need to store large quantities of proteins to meet the nutritional demand of seed germination and seedling emergence when protein degradation in the cotyledons is intense (Kim et al., 2011).

Based on the percentage of atom $\%{ }^{15} \mathrm{~N}$ excess, Ndff $(\%, \mathrm{mg})$ and Ndsr $(\%, \mathrm{mg})$ associated with the initial development of the seedlings (RL, RV and SL), it can be seen that in soybeans, the ability of the crops to accumulate nitrogen reserves during their developmental cycle is one of the decisive factors for the physiological quality of the seeds produced (Ishibashi et al., 2013; Narasimhan et al., 2013; Zimmer et al., 2016). Even though the $\mathrm{N}$ added via mineral supplementation was absorbed by the seeds, its contribution toward seedlings reaching autotrophic growth was, in this study, significantly lower than that of $\mathrm{N}$ from the cotyledon reserves. Thus, the seeds with a higher content of reserves and greater mobilization capacity produced seedlings with greater performance (Pereira et al., 2015); the application of mineral supplementation to soybean seeds to provide $\mathrm{N}$ is not an effective practice.

\section{CONCLUSIONS}

The seeds derived from the lot with less nutritional content absorb more $\mathrm{N}$ from the mineral supplement, which is accumulated in the cotyledons and redistributed to the roots and shoots. Most of the $\mathrm{N}$ in the organs of soybean seedlings over 10 days after sowing is derived from seed reserves in lots with low and high nutritional content. Thus, the application of $\mathrm{N}$ via mineral supplementation is of little importance to nutrition and seedling development.

\section{ACKNOWLEDGEMENTS}

We thank the financial support provided by the National Council of Scientific and Technological Development $(\mathrm{CNPq})$ and for providing scholarship to the first autor and for the productivity research grant for the second autor.

\section{REFERENCES}

BRASIL. Ministério da Agricultura e Reforma Agrária. Regras para análise de sementes. Brasília, DF: MAPA, 2009. 398p.

BRUNETTO, G. et al. Contribution of nitrogen from agricultural residues of rye to "Niagara Rosada" grape nutrition. Scientia Horticulturae, 169:66-70, 2014.

CAMPO, J. R.; ARAUJO, R. S.; HUNGRIA, M. Molybdenum enriched soybean seeds enhance $\mathrm{N}$ accumulation, seed yield, and seed protein content in Brazil. Field Crops Research, 110(3):219-224, 2009. 
CRUZ, C. D. Programa GENES: Estatística experimental e biometria. Viçosa - MG: UFV, 2006. 285p.

CHALK, P. M. et al. Methodologies for estimating nitrogen transfer between legumes and companion species in agro-ecosystems: A review of ${ }^{15} \mathrm{~N}$-enriched techniques. Soil Biology and Biochemistry, 73:10-21, 2014.

EMPRESA BRASILEIRA DE PESQUISA AGROPECUÁRIA EMBRAPA. Ambiente de software NTIA, versão 4.2.2: Manual do usuário - ferramental estatístico. Campinas: Centro Nacional de Pesquisa Tecnológica em Informática para a Agricultura. 1997. 258p.

GOYOAGA, C. et al. Content and distribution of protein, sugars and inositol phosphates during the germination and seedling growth of two cultivars of Vicia faba. Journal of Food Composition and Analysis, 24(3):391397, 2011.

HENNING, F. A. et al. Composição química e mobilização de reservas em sementes de soja de alto e baixo vigor. Bragantia, 69(3):727-734, 2010

ISHIBASHI, Y. et al. Regulation of soybean seed germination through ethylene production in response to reactive oxygen species. Annals of Botany, 1(11):1-8, 2013.

ISLAM, M. et al. Nitrogen redistribution and its relationship with the expression of GmATG8c during seed filling in soybean. Journal of Plant Physiology, 192(15):71-74, 2016.

$\mathrm{KIM}, \mathrm{H}$. T. et al. Mobilization of storage proteins in soybean seed (Glycine max L.) during germination and seedling growth. Biochimica et Biophysica Acta, 1814(9):11781187, 2011.

KRUEGER, K. et al. Phosphorus and potassium fertilization effects on soybean seed quality and composition. Crop Science, 53(2):602-610, 2013.

LIU, Q. et al. Nitrogen signaling and use efficiency in plants: What's new? Current Opinion in Plant Biology, 27:192198, 2015.

MILLER, A. J.; SHEN, Q.; XU, G. Freeways in the plant: Transporters for $\mathrm{N}, \mathrm{P}$ and $\mathrm{S}$ and their regulation. Current Opinion of Plant Biology, 12(3):284-290, 2009.

NARASIMHAN, R. et al. Differential changes in galactolipid and phospholipid species in soybean leaves and roots under nitrogen deficiency and after nodulation. Phytochemistry, 96:81-91, 2013.
OLIVEIRA, L. M. et al. Medição do $\mathrm{CO}_{2}$ como método alternativo para a diferenciação do vigor de lotes de sementes de melancia. Ciência Rural, 45(4):606-611, 2015.

PAUFERRO, N. et al. ${ }^{15} \mathrm{~N}$ natural abundance of biologically fixed $\mathrm{N} 2$ in soybean is controlled more by the Bradyrhizobium strain than by the variety of the host plant. Soil Biology \& Biochemistry, 42:1694-1700, 2010.

PEREIRA, W. A.; PEREIRA, S. M. A.; DIAS, D. C. F. S. Dynamics of reserves of soybean seeds during the development of seedlings of different commercial cultivars. Journal of Seed Science, 37(1):63-69, 2015.

RAMOS, M. S. et al. Characterization of a transport activity for long-chain peptides in barley mesophyll vacuoles. Journal of Experimental Botany, 62:24032410, 2011.

SAWAN, Z. M. et al. Effect of potassium, zinc and phosphorus on seed yield, seed viability and seedling vigor of cotton (Gossypium barbadense L.). Archives of Agronomy and Soil Science, 57(1):75-90, 2011.

SCHLERETH, A. et al. Comparison of globulin mobilisation and cystine proteinases in embryonic axes and cotyledons during germination and seedling growth of vetch (Vicia sativa L.). Journal of Experimental Botany, 51:14231433, 2000.

SEYYEDI, S. M. et al. Influence of phosphorus and soil amendments on black seed (Nigella sativa L.) oil yield and nutrient uptake. Industrial Crops and Products, 77:167174, 2015.

SHAH, A. R.; ARA, N.; SHAFI, G. Seed priming with phosphorus increased germination and yield of okra. African Journal of Agricultural Research, 6(16):38593876, 2011.

$\mathrm{SHAH}, \mathrm{H}$. et al. Seed priming improves early seedling growth and nutrient uptake in mungbean. Journal of Plant Nutrition, 35(6):805-816, 2012.

SHINMACH, I. F. et al. Influence of sulphur deficiency on the expression of specific sulphate transporters and the distribution of sulphur, selenium, and molybdenum in wheat. Plant Physiology, 153:327-336, 2010.

TAIRO, E. V.; NDAKIDEMI, P. A. Micronutrients uptake in soybean (Glycine max L.) as affected by Bradyrhizobium japonicum inoculation and phosphorus supplements. World, 1(1):19, 2013. 
TNANI, H. et al. ZmPTR1, a maize peptide transporter expressed in the epithelial cells of the scutellum during germination. Plant Science, 207:140-147, 2013.

TRIVELIN, P. C. O. Métodos de preparo de amostras para a determinação de ${ }^{15} \mathrm{~N}$. Piracicaba, 2001. 41p.

WANG, M.; FU, Y.; LIU, H. Nutritional quality and ions uptake to PTNDS in soybeans. Food Chemistry, 192(1):750759, 2016.
WHITE, P. J.; VENEKLAAS, E.J. Nature and nurture: the importance of seed phosphorus content. Plant Soil, 357(1):1-8, 2012.

YIN, X. et al. Effect of Nitrogen starvation on the responses of two rice cultivars to nitrate uptake and utilization. Pedosphere, 24(5):690-698, 2014.

ZIMMER, S. et al. Effects of soybean variety and Bradyrhizobium strains on yield, protein content and biological nitrogen fixation under cool growing conditions in Germany. European Journal of Agronomy, 72:38-46, 2016. 